\title{
Preben Kaarsholm
}

\section{Imperialisme og masochisme $\mathrm{i}$ Olive Schreiners romaner}

I både liv og værk frembyder Olive Schreiner en på én gang fascinerende og frastødende figur. Romanerne, som med enkelte forbehold aldrig er blevet rigtig populære eller vurderet litterært højt uden for Sydafrika, fremtræeder helt usammenhængende, deres narrative struktur er en ruin - de kunne tilsyneladende blive ved i al evighed og deres genre er mærkelig uspecifik, en tung blanding af realistiske, symbolistiske, allegoriske og filosofiske elementer, som er besværlige at læse.

$\mathrm{Da}$ jeg læste romanerne, oplevede jeg denne tyngde og brudthed kraftigt, men blev samtidig betaget af dem - af deres lidenskab og stilistiske originalitet og også af deres splittethed i sig selv. Tillige var der noget umådelig heroisk over den måde, forfatteren kcempede $\mathrm{med} / \mathrm{mod}$ sine romaner - det var kun The Story of an African Farm, der nåede at blive udgivet $\mathrm{i}$ hendes levetid; From Man to Man var ved at gøre hende vanvittig, blev revideret om og om igen og aldrig afsluttet. Jeg gav mig derfor til at nærlæse de tre tekster for at finde frem til, hvad der trods alt måtte findes af strukturerende princip under det tilsyneladende kaos, og hvad der mere præcist var de grundlæggende tematiske modsætninger, som romanernes diskus forsøgte at komme til rette med og udtrykke. Samtidig var jeg interesseret $\mathrm{i}$ at finde en forklaring på den paradoksale modsigelse, der syntes at foreligge mellem budskabet i Olive Schreiners romaner og $i$ hendes politiske skrifter.

Schreiners livshistorie, som for ikke så længe siden er blevet kortlagt $i$ en biografi af Ruth First og Ann Scott ${ }^{1}$, kan groft inddeles i fire afsnit. For det første perioden mellem Olive Schreiners fødsel i 1855 og 1881, som hun tilbragte i forskellige dele af Sydafrika, hvor hendes tyske far var en ikke særlig fremgangsrig missionær, der først arbejdede som lutheraner under London Missionary Society, senere som Wesley'sk metodist. Efter en kort periode i diamant-feltet omkring Kimberley, hvor hendes brødre søgte at gøre deres lykke, gik det meste af Schreiners ungdom med at arbejde som guvernante på afsidesliggende bondegårde $\mathrm{i}$ det store ørkenlignende område nord for Kaplandet, man kalder the Great Karoo, og det var her hun skrev sine første to romaner, Undine og The Story of an African Farm og påbegyndte sin tredje roman, From Man to Man. For det 
andet årene mellem 1881 og 1889, hvor Schreiner boede i London, fik The Story of an African Farm udgivet med en ikke ubetydelig succes og blev en kendt skikkelse $i$ venstrefløjsmiljøet. Det var i denne fase, at hun kom tæt på Havelock Ellis, Edward Carpenter, Eleanor Morx og Karl Pearson og var med til at starte Men and Women's Club. For det tredje perioden mellem 1890 og 1913, som dels blev tilbragt i Sydafrika, hvor Schreiner først var fascineret af, siden desillusioneret over Cecil Rhodes og imperialismen for så $\mathrm{i}$ årene op til Boerkrigen at fremstå som skarpsynet analytiker og kritiker af imperialismens dynamik. Efter krigen bevægede Olive Schreiner sig fra sit romantisk anti-kapitalistiske pro-boer-standpunkt frem til en mere raffineret og gennemtrængende forståelse af det sydafrikanske samfund og dets politik, $i$ årene frem til etableringen af den Sydafrikanske Union i 1910. De vigtigste værker fra denne periode er den anti-imperialistiske Trooper Peter Halket of Mashonaland (1897) og den feministiske klassiker Woman and Labour, som udkom i 1911. Endelig årene mellem 1913 og Schreiners død i 1920, hvor hun det meste af tiden boede i London, og som var præget dels af hendes engagement i pacifistisk politisk arbejde mod Verdenskrigen, dels af vaklende helbred og tiltagende almindelig frustration.

Jeg vil her beskæftige mig med en begrænset side af Schreiners ideologiske udvikling, nemlig kritikken af protestantismen $i$ hendes romaner og denne kritiks konsekvenser for udviklingen af hendes verdensanskuelse og politiske selvforståelse mere generelt. Alle Olive Schreiners tre romaner er i vigtige henseender 'teologiske romancer' eller 'fritænker-romaner', der gør oprør mod kristendommen som en del af et undertrykkende og udlevet verdenssystem og prøver at formulere alternativer.

Schreiners første roman Undine blev skrevet mellem 1873 og 1875 dels i Kimberley, dels i Fraserburg og Cradock, hvor forfatteren arbejdede som guvernante. Den blev udgivet posthumt i $1928^{2}$. Ligesom de to andre romaner er Undine stærkt selvbiografisk præget og tager udgangspunkt i en tematisk modsætning mellem børn og voksne og mellem barnets stræben frem mod frihed og autonomi på den ene side og en undertrykkende og psykologisk forkrøblende kristen opdragelse på den anden. Barnet er den 10-årige Undine Bock, der fra begyndelsen af beskrives som "en oprører" (s.21), de voksne, der betegnes som "de højere magter" (s.30), er hendes sydafrikanske familie, hendes stedfar, men mest betydningsfuldt hendes mor og guvernante. Den variant af kristendommen, som 
Undine indoktrineres med, er en blanding af calvinisme og metodisme.

Ábningskapitlet viser Undine mishandlet og undertrykt af religiøse forestillinger om skyld, straf og undergang i noget, der nærmer sig et angstneurotisk anfald: "... hun følte det, som om hun var ved at blive kvalt, og væggene og taget pulserede og bevægede sig ind på hende" (s.5). Romanens 'plot' udgøres af Undines bestræbelser for at overvinde undertrykkelsen, hvis paradigme er fastsat $i$ og med barndomsoplevelsen, og som senere antager varierende former især $\mathrm{i}$ hendes forhold til mænd og til sin egen seksualitet -og af oprørets nederlag i kraft af undertrykkelsens høje inderliggørelsesgrad. Et varsel om oprørsforsøgets uundgåelige nederlag optræder tidligt i romanen, hvor Undines bror Frank, der har foregrebet hendes udvikling ved at blive læge og ateist, og som på næsten incestuøs vis har harmoniseret konflikten mellem børn og voksne ved at etablere et lykkeligt kærlighedsforhold til tante Margaret, drukner på en måde, der genkalder Shelleys endeligt. Som konsekvens heraf forvandles den kærlige tante til en art vampyr:

" "Han plejede at sige, at der ikke fandtes nogen Gud og noget helvede, men nu skal Gud nok vise ham," ....Hun bed tænderne fast i Undines arm og knugede hende ind til brystet, indtil Undines skrig blev kvalt, og hun mistede bevidstheden. Da de, der havde hørt dem, kom ind i værelset, lå Undine sanseløs på gulvet, og i hjørnet længst væk krummede en ting sig sammen, slikkede de røde læber og skreg trimuferende, mens den pegede på hende: "Jeg har dræbt djævelen! Jeg har dræbt djævelen! Ha-ha-ha!" "(s.80)

Hermed har romanen introduceret sit bærende tema; der kan betegnes som 'oprørerens ambivalens', og som også tidligt i romanen repræsenteres af Undines vekslen mellem trods og desperat tvivl, frygt for kærlighedstab og drift mod selvødelæggelse: "Jeg ved, jeg er ond og syndig, og jeg er ligeglad, jeg er ligeglad, hvad der bliver af min sjæl, og jeg er ikke bange for noget som helst, ... A h, jeg ville ønske, jeg var død! Der er ingen, der ligner mig, og ingen der elsker mig. Åh, jeg ville ønske, jeg var død!" (s.31-2)

Som Schreiners andre romaner (og mange andre romaner fra perioden) er Undine i genremæessig henseende en blanding af naturalistisk realisme og symbolisme. Det symbolistiske islæt fremstår dels $\mathrm{i}$ form af allegoriske sekvenser - fortællinger inden i fortællingen - dels i form af episoder og billeder, hvor handlingen sættes i stå, og de centrale temaer opsummeres i en rakke symbolske $t a$ - 
bleau'er. Alle de vigtigste faser i udviklingen af romanens 'plot' markeres af sådanne symbolske opsummeringer. Efter de indledende kapitler er handlingens faser for det meste bestemt af Undines forhold til forskellige mænd - fætter Jonathan, Harry, George og Albert Blair, Bill Brown og endnu engang Albert Blair. Alle disse forhold er præget af den påvirkning, Undines kristne opdragelse har udøvet på hendes identitet, og defineres som sado-masochistiske forhold, hvor Undine skiftevis optræder som den dominerende og den dominerede pol. I hendes forhold til fætter Jonathan og Harry Blair, der begge beskrives som svage og kvindagtige mænd, optræder Undine som sadistisk herskerinde, som det tydeligt fremgår af den følgende tableau-agtige scene mellem hende og Jonathan:

"I lang tid stod den lille skikkelse i brun jakke og skotskternede bukser og kiggede i døren; til sidst kom den ind og knælede forsigtigt ned ved siden af hende... Hun for op og stødte ham fra sig og stod skælvende af raseri over ham. Stadig på knæ for hendes fødder greb den lille mand hendes hånd og stirrede op på ansigtet over ham. Selv i den svage belysning fra ildstedet, var det udtryk det bar af intens afsky synligt. Det bragte ham til fornuft igen. Han lod hånden falde og kravlede fuld af uudholdelig skamfølelse ud af værelset - næsten på hænder og fødder, som om han ville kravle ned i jorden og gemme sig." (s. 129-30)

En kontrast hertil udgøres af Undines fascination af den fallisknarcissistiske Albert Blair, hans "lækre gyldne overskæg" (s. 127) og hans totale kontrol over sin hund, som Undine drømmer om at identificere sig med - $\mathrm{i}$ en sådan grad at fortælleren kalder hende "menneske-hunden" (s. 146): "Åh, Prins! Jeg ville ønske, jeg var dig! Jeg har ikke lyst til at blive elsket; jeg har kun lyst til at elske noget" (s. 133) eller "Hvor må det være dejligt at have noget, man må adlyde..." (s. 127) Hendes underkastelse i forhold til Albert er så betingelsesløs, at hun endog adlyder hans påbud om at gå i kirke på trods af alle oprørske forsætter om at bryde med kristendommen (s. 147). Undines forhold til Albert Blair opsummeres i hendes fortolkning af et oliemalet tableau af en døende kriger på slagmarken, hvis fødder lidenskabeligt omfavnes af en vellystig, halvnøgen kvinde:

"Det fortæller sin egen historie, ....Han var en ædel herre af blodet og hun en fattig træl, som kun havde sin sjæl og sit smukke legeme at give ham. Han gad knap tage imod dem; selvom det intet kostede; og nu i dødens stund er hun fulgt efter ham og har fundet ham død og krummer sig sammen ved hans fødder i smerte, fordi han er væk, og i vild fryd fordi han nu er hendes alene - hendes og 
ingen andens, hvis blot hun må få lov at ligge ved hans fødder og dø dér." (s. 103)

Undine svigtes af Albert, afslår hans kvindagtige brors ægteskabstilbud og gifter sig i stedet med hans far i noget, der ligner endnu et forsøg på at slå bro over kløften mellem børn og forældre. Faderens magt er ikke baseret på seksualitet, men på penge og forekommer derfor Undine mere overkommelig. Fortælleren sammenligner de to former for magt på følgende måde: "Ak ja, guld og kærlighed, det er de store guder, som behersker os! Guld - gud over kroppen med dens lyster og dens lér; kærlighed - gud over sjælen med dens ild og dens lidenskab" (s. 121). Derudover giver ægteskabet med George Blair Undine mulighed for indirekte at underkaste sig og tjene Albert, som er dybt forgældet, ved anonymt at overdrage ham de $£$. 50.000 , hun har sat som sin pris for at gifte sig med faderen. Denne underlæggen sig noget $i$ retning af prostitution fremstilles $i$ romanen som det, der frelser Undine fra selvmord (s. 174).

Handlingens sidste fase udspiller sig efter Undines mands død, da hun $i$ et nyt forsøg på at skaffe sig frihed og uafhængighed rejser til de nyligt åbnede diamant-udgravninger i New Rush - Kimberley - i Sydafrika:

"Hvorfor skulle en kvinde ikke bryde de konventionens bånd, der afkræfter hendes sind og forkrøbler hendes krop, og opleve et vildt, frit, sandt liv, som en mand kan? - vandre ud i den grønne verden og bruge sine hænder og fødder og leve et frit, stormende liv uden at være en mands slave? - glemme den gamle morbide kærlighed og længsel? - leve og hengive sig og lære så meget hun kan, før stilheden kommer?" (s. 244-5)

Ikke desto mindre udgøres hele denne del af romanen af en lang serie ydmygelser og underkastelser, gennem hvilke Undine ved at plage og ofre sig selv søger at finde livets mening. Midt i det kapitalistiske mareridt i Kimberley etablerer hun sig som vaskekone og får et vist mål tilfredsstillelse ud af at pleje og frelse den syge diamantgraver Bill Brown. Igen opsummeres Undines forsøg på selvrealisering gennem opofrelse og ydmygelse i en tableau-agtig situation, hvor Bill ligger på en båre, mens Undine sidder på gulvet ved hans fødder og stopper hans strømper. (s. 344)

Handlingens højdepunkt nås imidlertid, da Undine på mirakuløs vis genfinder sin elskede Albert i Kimberley, hvor han netop er død, og opnår sit livs mål og den endelige tilfredsstillelse gennem at tilbringe en nat alene sammen med hunden Prins og Alberts afsjælede legeme. For sidste gang understreger romanen sin pointe $\mathrm{i}$ 
opbygningen af et symbolsk tableau, som denne gang er af næsten nekrofil karakter:

"Hun tog lagenet væk fra hans ansigt, og den levende kvindes kind trykkedes tæt mod den døde mands kolde ansigt. I hans øre hviskede hun vilde kærlighedsord, som hun aldrig ville ytre til de levende - vilde, lidenskabelige ord, udgydelser af et helt livs knuste kærlighed, en eruption af voldsomt undertrykt lidenskab. Og den døde mand ligger så stille; han sender hende ikke væk; han beder hende ikke tie; nu forstår han hende; nu elsker han hende. Hun vil se hans ansigt endnu en gang, før det bliver borte, så vil hun krybe tæt ind til ham og ligge dér og aldrig forlade ham." (s. 363)

Undine dør dog ikke midt i denne orgiastiske oplevelse, men umiddelbart efter - ude $i$ det fri under den sydafrikanske himmels stjerner. Med hundens hovede hvilende på sit bryst oplever hun her en vision af universets sammenhæng og mening, som endelig giver hende et alternativ til den protestantiske kristendom, hun har brugt sit liv på at gøre oprør imod. En stjerne taler til hende:

" "Hvis det du frygter i den død, der kommer til dig nu, ikke er forandringen, men en frygtelig, uendelig stilhed og tilintetgørelse, så vær rolig", sagde stjernen; "jeg har været ung og er nu gammel; jeg har set voldsom flod og ebbe og en myriade af omskiftelser uden ende; men en død som den du drømmer om har jeg intetsteds set. Naturen er for fattig til at give afkald, for fattig til at lade noget ligge; dens værk er endnu ikke afsluttet; den har endnu ting at skabe." "(s. 372)

Den alternative verdensanskuelse, som Undine til sidst når frem til, er en holistisk evolutionisme i Herbert Spencers manér, hvor den tomhed, der udspringer af tabet af den kristne tro, udfyldes med en sammenhæng og mening, som tillægges det naturlige univers i sig selv - hvorigennem livets og dødens byrde bliver lettere at bære ${ }^{3}$.

Olive Schreiners næste roman The Story of an African Farm (dansk oversættelse ved Inger Bang, Kbh. 1980) blev skrevet mellem 1875 og 1879 og udgivet i London i $1883^{4}$. Romanen er en blanding af tre forskellige genrer: Den rummer elementer af en naturalistisk roman, der stræber frem mod en psykologisk analyse af en bestemt menneskelig livssituation, af allegori og af en politisk-filosofisk traktat, der beskæftiger sig med universets orden og mening og med menneskets frihed. Tilsyneladende er disse forskellige genrer selvstændiggjorte i forhold til hinanden i romanen: Den naturalistiske fortælling behandler livet på gården og de indbyrdes forhold mellem hovedpersonerne; allegorien kommer ind i den fabel, den frem- 
mede fortæller Waldo i anden dels andet kapitel og i drømmesekvenserne; og den politiske og filosofiske diskurs træder til i kapitlet 'Tider og årstider' og i Lyndall's monolog i anden dels kapitel fire. Romanen fremtræder som collage, som en selvmodsigende og uharmonisk sammenrodning af genrer, som forfatteren ikke har været $i$ stand til at smelte sammen til noget enhedsligt og selvstændigt. Som homogent og meningsfuldt kunstværk synes African Farm at slå fejl. Også forsảvidt angår fortælleteknikken, forekommer romanen at falde fra hinanden og er ikke æstetisk tilfredsstillende.

Det står klart fra romanens begyndelse, at dens naturalisme er helt overfladisk, og at dens diskurs er gennemsyret af symbolisme. De første to dele af første kapitel modstiller gården og dens mennesker, som de fremtræder ved nat og ved dag for at understrege, at virkeligheden ikke kan fattes alene gennem empirisk tilgang, at den samme ydre verden kan fyldes med forskellige former for indre mening. Den ydre verden er både sig selv og noget andet, noget symbolsk, der er bestemt af den optik, hvorigennem der gåes til den. Det gælder for eksempel Tant' Sannies optik, der i drømme er determineret af hendes aftensmåltid, eller mere vigtigt Waldos, som først og fremmest er formet af den lutheranske skyld-og selvhadsideologi, som hans tyske far har påtvunget ham. Om dagen er objektiviteten tilsyneladende sig selv, om natten truer subjekternes indre liv dens integritet. The Story of an African Farm prøver at fremstille en virkelighed, der ligger hinsides det, der umiddelbart kan ses om dagen, og $\mathrm{i}$ bogens første kapitel præsenteres dette 'hinsides' som tematisk modsætning mellem magt og magtesløshed, der viser sig at være grundlæggende hele romanen igennem.

Grundmodsætningen mellem magt og magtesløshed manifesterer sig på flere forskellige niveauer og gennem forskellige motiver. Den fremstår f.eks. som modsigelse mellem Gud og menneske i Waldos religiøse krise; som modsigelse mellem voksne og børn eksempelvis i de scener, der omhandler forældre og afkom, Bonaparte Blenkins og Waldo og Waldo og hans fremmede; som modsætning mellem mand og kvinde f. eks. i Lyndalls monolog, i forholdet mellem Lyndall og hendes fremmede og i de scener, der omhandler Gregorys forvirrede forhold til sin seksuelle identitet. Den manifesterer sig også som kontrast mellem by-og landliv og mellem briter og boere i de af romanens dele, der f.eks. modstiller den civilisation, der kendetegner Bonaparte Blenkins, Ems far eller Gregory Rose, med boer-fællesskabets kultur.

På tilsvarende vis gennemtrænger modsigelsen mellem magt og 
magtesløshed de strukturelle relationer mellem romanens hovedpersoner. Karligheden, som den fremstilles i forholdene mellem Lyndall og hendes fremmede, Waldo og hans fremmede, Em og Gregory og Gregory og Lyndall, er væsensbestemt ud fra magt og underkastelse. Det er imidlertid karakteristisk, at de to poler er ombyttelige: I forhold til Waldo repræsenterer hans far magten, i forhold til Bonaparte Blenkins magtesløsheden; i forhold til Waldo repræenterer Bonaparte magt, i forhold til Tant' Sannie eller Lyndall magtesløshed; i forhold til Gregory repræsenterer Lyndall magten, til den fremmede magtesløsheden. I det hele taget synes de fire hovedpersoner - Lyndall, Waldo, Em og Gregory - ikke så meget at udgøre selvstændige karakterer som forskellige sider af en hel personlighed, der konfligerer med og supplerer hinanden, en personlighed, der i sig rummer både magten og magtesløshedens komplementære poler. Analyseret psykologisk kan grundstrukturen i $\mathrm{Afri}$ can Farm således betegnes som narcissistisk, som væsentligst omhandlende kontrasterende billeder af samme personlighed ${ }^{5}$. Eller den kan måske mere adækvat beskrives som sado-masochistisk, som kredsende omkring dominans- og underkastelsesmønstre. Svarende hertil er romanens 'plot' i psykologiske termer konstrueret omkring projekter rettet mod frigørelse forstået som nedbrydning af disse mønstre og forsoning af deres modsætninger.

Jeg sagde ovenfor, at The Story of an African Farm beskæftiger sig med to former for virkelighed - en materiel og en transcendental - og har forsøgt at vise, hvordan den hinsides verden fremstilles som en række psykologiske determinationer. Men også i en anden forstand gælder det, at "the material world is but a film" (s. 119, cf. da. overs., s. 99). Som alternativ til en kristen religiøs livsforståelse fremlægger African Farm en ateistisk, evolutionistisk og transcendentalistisk verdensanskuelse - inspireret af Spencer og Emerson. Således kan romanens dødsfascination såvel forklares psykologisk som masochisme, og som resultatet af frigørelsesprojekternes tragiske fejlslag, der forståes $\mathrm{i}$ forhold til et evolutionistisk og holistisk verdenssyn, som hævder, at der findes en mystisk identitet mellem det individuelle og det universelle, og betragter ét evolutions-stadiums sammenbrud som forudsætning for udviklingen af et nyt og mere fremskredent. Selv denne evolutionistiske verdensanskuelse har et element af masochisme i sig: Individet underkaster sig universets evolutions-love på en måde, der er parallel til den kristne underkasten sig Gud.

Det er på dette niveau, at man kunne hævde, at The Story of an 
African Farm trods alt bygger på en slags kunstnerisk énhed: Parallellen mellem den psykologiske og den universelle virkelighed kan siges at retfærdiggøre sammenbringningen af de forskellige naturalistiske, allegoriske og filosofiske genrer og diskurser.

De væsentligste dele af Schreiners tredje roman From Man to Man blev skrevet mellem 1876 og 1889, men teksten blev underkastet endeløse revisioner $i$ hele forfatterens levetid og var endnu uafsluttet ved hendes død i 1920. Den blev udgivet posthumt i $1926^{6}$. Ligesom Undine og African Farm begynder From Man to Man med fremstillingen af en barndomssituation, hvor én af hovedpersonerne underkues af de voksne og deres opdragelsesideologier. Men denne gang er den kristne religion ikke så centralt placeret som i de tidligere romaner - $\mathrm{i}$ stedet giver 'The Prelude' læseren en detaljeret oversigt over de kulturelle ingredienser $i$ en hvid koloni-opdragelse i Sydafrika i slutningen af det 19. århundrede. Disse strækker sig fra læsningen af opbyggelige historier om tapre britiske damers prøvelser under det Indiske Mytteri til skrækpropaganda mod for meget solskin, som gør børn sorte som 'kaffirs' (s. 53-4, s. 60). Men resultatet er mere eller mindre det samme: I åbningssekvensen fremstår den 5 -årige Rebekah som gennemgribende indoktrineret med skyld-, selvhads- og selvødelæggelses-følelser - "Åh, jeg ville ønske, jeg var død - jeg ville ønske, jeg var død - jeg ville ønske, jeg var død!" (s. 72) Rebekah identificerer sig selv med en slange og har "en følelse af, at hele verden er ryggesløst ond og syndefuld" (s 62).

Romanen er historien om to søstre, der på forskellige måder lever de determinationer ud, som deres opdragelse og kultur har påtvunget dem, samtidig med at de forsøger at fri-og virkeliggøre sig selv som autonome individer - Rebekah som hustru og mor, Bertie som 'falden kvinde'. I Berties tilfælde er 'faldet' en direkte konsekvens af barndomsprægninger: Det er hendes drift mod selvunderkastelse, der får hende til at lade sig forføre af sin huslærer, og som dernæst får hende til at tilstå det skete for sin religiøse fætter John-Ferdinand, der gerne vil giftes med hende, men ender med at starte den sladder, der bliver Berties skæbne. De resterende dele af Berties udvikling i romanen består i hendes anger og ydmygelse, der til slut får hende til at give sig hen til en hæslig jøde, som tager hende med til London, hvor hun senere forsvinder i Sohos bordelverden. 


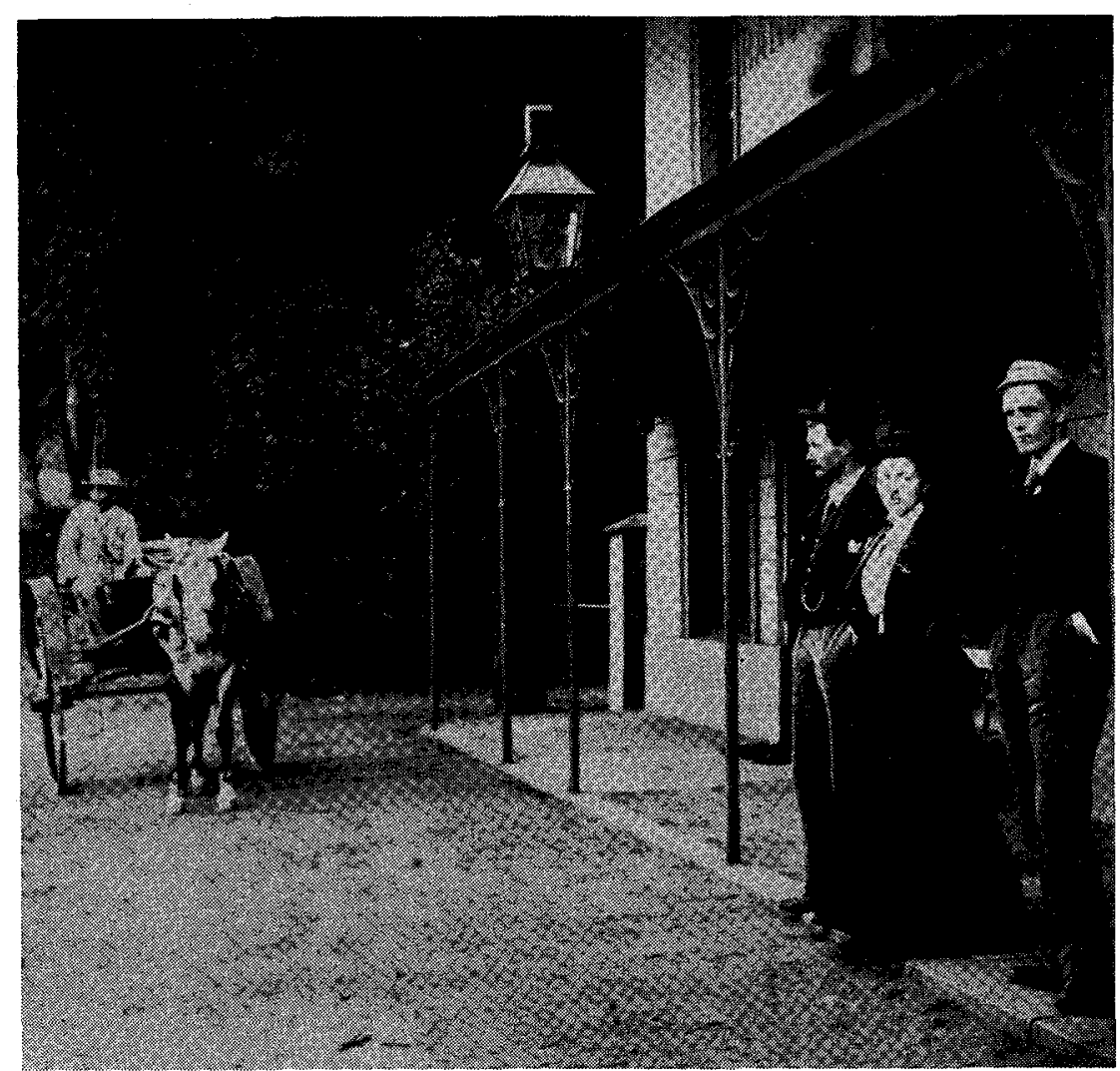

'Waiting on the Porch. Cape Town 1894.' Billedet kunne næsten være en illustration til Rondebosch-sekvenserne i sidste del af Olive Schreiners From Man to Man. Det fanger skarpt den blanding af bornert kedsomhed og forventninger til et nyt liv, der præger britisk kolonikultur i slutningen af forrige århundrede. (Fra Jan Morris: The Spectacle of Empire. Style, Effect and the Pax Britannica, New York 1982)

Romanens hovedhandling drejer sig om Rebekah, der prostituerer sig på anden vis ved at leve $i$ et ulykkeligt ægteskab med en svag og selvisk mand, der udbytter og bedrager hende - ydmygelsen når sit højdepunkt i mandens affære med familiens farvede tjenestepige og indlemmelsen af det resulterende barn i hjemmet $i$ Rondebosch. Hovedspændingen i romanens temmelig tynde 'plot' går mellem Rebekahs spontane tilbøjelighed til at underkaste sig mandens urimelighed og familierollens krav på den ene side og på den anden hendes modstand og kamp for at opbygge et frit og uafhæengigt liv for sig selv. Mere end en femtedel af romanens næsten 500 sider optages af Rebekahs forsøg på gennem spekulation at legitimere sin 
modstand og udarbejde en sammenhængende livsfilosofi. Der består en vigtig forskel mellem From Man to Man og de to tidligere romaner, forsåvidt som hovedpersonens bestræbelser denne gang ikke ender i død og selvudslettelse. Romanen er uafsluttet, men dér hvor fragmentet holder op, møder Rebekah en alternativ mandstype, Drummond, som respekterer hende som autonomt individ og forstår og sympatiserer med hendes livsfilosofi, hvorved der bringes et optimistisk perspektiv ind $\mathrm{i}$ romanen, som er fraværende $\mathrm{i}$ de tidligere romaner.

Rebekahs livsfilosofi er et forsøg på at få styr på det, hun kalder "den moderne følelse" (s. 177), dvs. den oplevelse af tomhed og referenceforfald, der er kommet ud af kristendommens sammenbrud som verdensanskuelse og moralsk målestok. Hun begynder med at prøve at gå bag om kristendommen til antikkens naturfilosofier, fordi disse efter Rebekahs mening forsøgte at nærme sig tingene, som de er, mens kristendommen mest af alt har betydet et ødelæggende hykleri, som har berøvet store områder af den indre og ydre virkelighed deres eksistensret. På dette grundlag opridser hun en holistisk og evolutionistisk anti-religion, der er parallel til de tilsvarende forsøg, som gøres af hovedpersonerne i Undine og African Farm og på samme måde inspireret af Spencer, men som nu præsenteres i langt mere udfoldet form. Forsåvidt som Rebekah er talerør for forfatteren, udgør disse afsnit den mest fuldstændige fremstilling, der findes, af Olive Schreiners filosofi.

Hovedpunkterne i Rebekahs verdensanskuelse og frigørelsesprogram kan opsummeres som følger. For det første er verden og universet et udeleligt hele. Der består en mystisk korrespondens mellem del og helhed - helheden kan findes og forståes i sin mindste bestanddel, og hver del har en eksistens uden for sig selv i helheden. Ved hjælp af denne holistiske opfattelse udstyres universet med en transcendental 'mening', der udfylder det tomrum, som kristendommens forfald har efterladt. For det andet gør universet historisk set fremskridt gennem en evolutions-proces, hvorved helheden opnår en stadig større grad af kompleksitet og differentiering. Når helhedens differentiering har nået sit højdepunkt - hvad det så end betyder - bryder den sammen og viger pladsen for en ny og 'højerestående' totalitet. Evolutionsprincippet gælder både i naturhistorien og i samfundsmæssige og kulturelle helheders udvikling. For det tredje afleder Rebekah af denne holistiske evolutions-'lov' nødvendigheden af en radikal demokratisering: Hun påviser, hvordan fremskridtet forsinkes eller standses, hvis ikke alle dele af helheden 
har del i det: "...hvor de mange bliver ladt i stikken, vil de få også før eller senere blive trukket tilbage...det menneskelige fremskridts sande kampråb vil altid være "Få bagtroppen med frem! Få bagtroppen med frem!...Et varigt menneskeligt fremskridt må være et samlet fremskridt!". (s. 191-2) Således er frigørelsen af kvinderne og andre undertrykte grupper i samfundet påkrævet for at sikre det videre fremskridt og nødvendiggjort af naturen og universets orden. Endelig konkluderer Rebekah som noget nyt i sammenligning med Schreiners tidligere fremlæggelser af sin evolutionisme med en relativistisk definition af civilisation, som indebærer, at ingen del af helheden, intet enkelt samfund, ingen enkeltstående race eller samfundsgruppe er i stand til at dømme om andre dele, samfund, racer eller gruppers eksistensret eller 'tilbageståenhed'. Det hedder f. eks. $i$ en formulering, der kritiserer eugenik og 'social efficiency'-tænkning: "...man kan ikke opregne en lang liste af ønskelige eller ikkeønskelige menneskelige egenskaber, som alle samlet findes hos en enkelt race eller et enkelt individ" (s. 196). Definitionen fremføres også som kritik af imperialistisk-chauvinistiske anvendelser af begrebet civilisation:

"...det tilkommer ikke os som den sidst tæmmede af alle civiliserede racer at tale nedladende om primitive barbarer;..Vi taler om, at de gamle civilisationer nær var uddøde på grund af overdreven civilisering; et tilbagefald til det nøgne liv i skovene og nomadernes telt-liv var nødvendigt for at give dem ny vitalitet...er det ikke muligt, at de primitive folk på samme måde - individuelt, strukturelt og samfundsmæssigt - i en fremtidig tidsalder kommer til at opfylde den genoprettende funktion for os, som vi forestiller os at have udøvet $\mathrm{i}$ forhold til tidligere dekadente civilisationer?"(s. 204-5) ${ }^{7}$

Rebekahs evolutionsdoktrin lægger vægt på $i k k e$ at være en teori om 'the survival of the fittest' - hun hæuder forældrenes kærlighed og omsorg som fremskridtsbetingelser, der er lige så vigtige som den rå, instinktive drift mod overlevelse. Evolution og fremskridt folder sig ikke ud på mekanisk eller 'lineær' facon - de kan fremmes ved hjælp af fornuften eller aktiv menneskelig praksis, eller de kan hæmmes og forsinkes af ufornuft og undertrykkelse.

Det er på basis af denne verdensanskuelse, at Rebekah i slutningen af From Man to Man i forhold til sine børn og stedbarnet Sartje (resultatet af hendes ægtemands extravaganza) giver et eksempel på en alternativ borneopdragelse, der skal fungere som modstykke til de destruktive og undertrykkende resultater af en protestantisk kri- 
sten opdragelse, der er udgangspunktet i alle Schreiners romaner.

Evolutionismen i From Man to Man er betydelig mere raffineret end den temmelig mekaniske og racistiske teori om udviklingsstadierne, der fremlægges i Undine og The Story of an African Farm. Man behøver blot sammenligne Rebekahs teorier med African Farms gentagne klassificering af hunde og 'kaffirs' som hørende til de lavere evolutionstrin eller med Undines oplevelse af de sorte afrikanere i Kimberley:

"Det var herligt at være alene igen. Alene selvom gaden var myldrende fuld af de mange niggere og digger'e [diamantgravere], som var på vej hjem fra arbejde og sparkede det røde sand op i glødende skyer over deres hoveder - splitternøgne vilde fra dybt inde i landet med deres krogede edderkoppebén og grovkæbede, pandeløse abe-ansigter, der, som om de var på vej hjem til bålet og maden, næppe kunne løsrive sig fra den vante kravlen - koloni-niggere, som var halvt påklædte uden at være halvt civiliserede og med nogle hundrede procent mere ondskabsfuldhed i deres sorte fjæs end deres mere vilde brødre - store muskelsvulmende fyre, næsten højere og stærkere end deres herrer, de hvide digger'e, der kun udgjorde et spinkelt islæt i mængden, og som på trods af de støvskyer, der omgav dem, kunne kendes på deres hurtigere og mere energiske bevægelser." (s. 281)

Men også i From Man to Man resterer der et kraftigt element af racisme eller måske rettere en modsigelse mellem en 'spontan' racisme og en række intellektuelle forsøg på at overvinde den. Der er f. eks. et klart racistisk perspektiv i den stereotype, romantisk antikapitalistiske beskrivelse af den jødiske finanskapitalist, der trækker Bertie med sig til London ${ }^{8}$. Der er tilsvarende et element af racisme i den nedladenhed, der kendetegner Rebekahs civilisationsteori, og mere praktisk i hendes måde at tage sig af Sartje på. Denne modsigelse mellem en 'spontan' racisme og intellektets forsøg på at overvinde den præsenteres helt direkte $i$ slutningen af romanen, hvor Rebekah henvender sig til sine børn og dels vil have dem til at holde op med at opføre sig racistisk mod Sartje, dels giver udtryk for sin forståelse for dem:

"Jeg er jeres mor og tre gange ældre end I, og jeg burde være langt klogere, men når jeg går ned ad Government Avenue, og de farvede piger, der sidder langs gaden, griner af mig, fordi de kan se, jeg ikke går med korset som andre kvinder, så er det som om der blev stukket en kniv ind mellem mine ribben. Jeg ved, jeg har ret, og at folk engang $i$ fremtiden vil undre sig over, hvorfor 
kvinder kunne være vanvittige og tåbelige nok til at gøre sig selv deforme. Og alligevel, når de dér griner af mig, gør det så ondt på mig, at jeg næsten ikke kan gå ned til stationen; og når jeg er kommet hjem, har jeg kun lyst til at gå i seng og græde. Jeg har prøvet at holde af de farvede kvinder og gøre alt hvad jeg kan for at hjælpe dem, og så håner de mig! I dagevis efter har jeg ikke lyst til at gå ud igen. Hvis jeg - jeres mor, som burde være meget stærkere og klogere - føler tingene på den måde, hvilken ret har jeg så til at forvente, at små drenge som. I kan klare dem. I ville være helte, hvis I kunne." "(s. 440)

De racistiske og imperialistiske aspekter af Olive Schreiners evolutionisme står tilsyneladende $\mathrm{i}$ grel modsætning til udviklingen $\mathrm{i}$ hendes politiske tankegang. Som det er almindelig kendt, var Schreiner fra midten af halvfemserne og fremefter én af de mest fremtrædende kritikere af den aggressive britiske imperialisme i Sydafrika. I Trooper Peter Halket of Mashonaland (1897) præsterede hun en klassisk fordømmelse af British South Africa Company og Cecil Rhodes' aktiviteter under Ndebele-oprøret og et magtfuldt opgør med racismen ${ }^{9}$. I årene op til og under Boerkrigen skrev hun artikler og taler, hvor hun modstillede boernes sunde og organiske bondesamfund med den urbane kapitalismes frivolitet og dekadence, som den repræsenteredes af den britiske imperialisme ${ }^{10}$. Efter krigen forfinedes hendes imperialismekritik i hendes angreb på briterne og boernes ulyksalige alliance i retning af skabelsen af et statsapparat, hvis primære mål og funktion var og er at sikre grundlaget for en ekstrem udbytning af den ikke-hvide arbejdskraft .

Men Olive Schreiner nåede ikke frem til sit anti-imperialistiske standpunkt, før hun havde gennemgået en fase, hvor hun var klart tiltrukket af imperialistiske tankemønstre, og selv hendes anti-imperialisme blev ved med at rumme elementer af imperialistiske ideologi. I de sene 1880ere og tidlige 1890ere var Schreiner fascineret af og tæt knyttet til imperialistiske personligheder som Rhodes, som hun på det tidspunkt opfattede som "det eneste geniale menneske" i en verden af sydafrikansk, småborgerlig middelmådighed ${ }^{11}$. I denne periode omgikkes Olive Schreiner også imperialistiske tænkere som Kipling, W. T. Stead og Arnold White og gennemlevede en krise af lidenskabelig forbundethed til Karl Pearson, der blev den førende talsmand for iværksættelsen af eugeniske politiske tiltag inden for rammerne af en imperialistisk stat ${ }^{12}$. Endda $i$ hendes senere skrifter som Woman and Labour (1911) finder man umiskendelige spor af imperialistisk ideologi i form af eugeniske spekulationer. 
Hvad var det, der gjorde et imperialistisk tankemønster så tiltrækkende og i visse henseender næsten uundgåeligt for Olive Schreiner? For det første er der en vis masochisme, "den gamle morbide kærlighed og længsel," hun skriver om i Undine, i hendes besathed af 'store mænd', af magtfulde imperialistiske personligheder som Pearson og Rhodes ${ }^{13}$. Tilsvarende forekommer seksualitetsangst at være en motiverende faktor bag dele af Schreiners racisme: Både i Undine og From Man to Man er der passager, hvor sorte afrikanere gøres til billeder på mandlig seksualitet ${ }^{14}$. Det synes, som om disse psykologiske karakteristika - masochismen og seksualitetsangsten der trakker i retning af en imperialistisk mentalitet, har deres baggrund i Schreiners strenge protestantiske opdragelse, på samme måde som et masochistisk beredskab bringes til veje hos personerne $\mathrm{i}$ hendes romaner. Forbindelsen sandsynliggøres yderligere af det forhold, at den lutheranske og metodistiske kristendom, som Schreiner blev opdraget med i sit sydafrikanske missionærhjem, direkte blev anvendt som legitimation for den aggressive imperialisme - bl. a. af London Missionary Society, som først sendte hendes far ud til Afri$\mathrm{ka}^{15}$.

For det andet og mere direkte var en imperialistisk verdensanskuelse tiltrækkende for Olive Schreiner som et alternativ til den protestantiske kristendom. I vigtige henseender formuleres den evolutionisme, der er hendes mest omfattende bud på en sammenhængende livsfilosofi som en anti-religion, som noget, der kan udfylde tomrummet efter den kristendom, hvis destruktive indflydelse hun forsøgte at befri sig fra.

\section{Noter}

1 Ruth First og Ann Scott: Olive Schreiner, Andre Deutsch, London 1980.

2 Olive Schreiner: Undine, Harper, N. Y. og London 1928, genoptrykt Johnson Reprint Corporation, N. Y. og London 1972. Citaterne er fra denne udgave

3 Sml. Herbert Spencer: First Principles, London 1862 og J.W. Burrow: Evolution and Society. A Study in Victorian Social Theory, Cambridge University Press, Cambridge 1966, kap. 6.

4 Ralph Iron [Olive Schreiner] : The Story of an African Farm, Chapman and Hall, London 1883. Citaterne er fra tredje udgave, 1887. Den danske oversættelse er udgivet af forlaget Hekla.

5 Sml. også Lyndalls optagethed af spejle, f. eks. i dødsscenen, s. $275 \mathrm{ff}$. 
6 Olive Schreiner: From Man to Man, or Perhaps Only, Fisher Unwin, London 1926, genoptrykt Virago Press, London 1982. Citaterne er fra denne udgave.

7 Lignende forestillinger om komplementariteten mellem 'civilisation' og 'barbari' kan findes hos imperialistiske forfattere som Kipling (i Kim f. eks.) eller George Steevens, Daily Mails stjernereporter. Sml. f. eks. G. W. Steevens: 'From the New Gibbon', Blackwood's Magazine, februar 1899 og mine artikler 'Imperialism and New Journalism', i Breitinger og Sander (udg.): Studies in Commonwealth Literature, Günther Narr, Tübingen $1985 \mathrm{og}$ 'Kipling, Imperialism and the Crisis of Victorian Masculinity', i Samuel (udg.): Patriotism, Routledge and Kegan Paul, London 1985.

8 Se s. 328ff. hvor jødens udseende, sprog og karakteristiske beskæftigelse skildres.

9 Det er værd at bemærke, at Trooper Peter Halket of Mashonaland er dediceret til Sir George Grey, "som vi idag husker som repræsentant for de ædleste sider af et imperialt styre" (Fisher Unwin, London 1897, s. 9). Schreiner stiller således en økonomisk udbytnings-imperialisme over for en politisk opdragende variant, som hun kan tilslutte sig.

10 Se Olive Schreiner: Thoughts.on South Africa, Fisher Unwin, London 1923. Sml. First og Scott, op. cit., s. 224f., der gør det klart, at Schreiners forelskelse i boerne var helt énsidig.

11 Se The Letters of Olive Schreiner, udg. af S. C. Cronwright-Schreiner, Fisher Unwin, London 1924, s. 206ff. Det er interessant, at Rhodes tilsyneladende var stærkt optaget af The Story of an African Farm, jf. S. C. Cronwright-Schreiner: The Life of Olive Schreiner, Fisher Unwin, London 1924, s. 208ff.

12 Se First og Scott, op. cit. Sml. om Pearson Anna Davin: 'Imperialism and Motherhood', History Workshop Jounal, 5, 1978.

13 Der synes også at have været tale om en stærk masochistisk komponent i hendes tiltrækning til ægtemanden Cron. Se hans beskrivelser af deres første møde i december 1892 i hans Life of Olive Schreiner, s. 233ff.

14 Se f. eks. beskrivelsen af Albert Blairs "meget sorte nigger" i Undine, s. 350. Sml. den unge Rebekahs udsagn i From Man to Man: "Jeg kan ikke lide drenge, de minder om 'kaffirs'...jeg er glad for, jeg ikke er en 'kaffir'mands kone" (s. 56).

15 Se First og Scott, op. cit;, s. 28ff. Sml. Patricia Knight: 'British Public Opinion and the Rise of Imperialist Sentiment in relation to Expansion in Africa', University of Warwick 1968, s. $222 \mathrm{ff}$. 